\title{
Problematika Geng Motor di Kabupaten Kuningan dalam Prespektif Sosiologi Hukum*
}

\author{
Diding Rahmat \\ Fakultas Hukum Universitas Kuningan \\ E-mail : petrik_rahmat@gmail.com
}

\begin{abstract}
Brutality motorcycle gang is due to the social phenomenon of metamorphosis and development of information technology then is not filtered and not accommodated komferhensip about how pencegahanya action, it is the analysis that the majority of gang members are children that have motors and often commit crimes and violate social norms there. As a result of the brutal and unlawful actions that ultimately the future of motorcycle gang members tend to be aged under child protection laws they are still called the future of their children because they have to face a bleak life in bars and deprived of their freedom of expression, it is different with children outside bars detainees who have the freedom to express and execute education as befits a normal child his age . Factors behind them consists of internal factors and external factors, internal factors such as for some is not healthy mental attitude of a motorcycle gang members, disharmony in the family, an outlet disappointment, the economy needs a boost, aberrant learning process, lack of attention and affection as well as low levels of education among them while external factors, namely the need for law enforcement officers to always take preventive actions in handling cases motorcycle gangs and local community participation in order to swiftly carry out preventive.measures.as.well

Keywords: Problems , Gank , Motorcycle , Sociological
\end{abstract}

Abstrak
Tindakan brutal geng motor merupakan fenomena sosial akibat metamorfosa
perkembangan tekhnologi dan informasi yang kemudian tidak terfilter dan tidak
terakomodasi secara komferhensip tentang bagaimana tindakan pencegahanya, hal ini
dengan analisa bahwa mayoritas dari anggota geng adalah anak yang memilki motor
dan kerap melakukan tindakan kriminal dan melanggar norma sosial yang ada. Akibat
tindakan brutal dan melanggar hukum tersebut akhirnya masa depan dari anggota
geng motor yang cenderung secara usia menurut undang-undang perlindungan anak
mereka masih dinamakan anak maka masa depan mereka suram karena harus
menghadapi hidup di jeruji besi dan kebebasan mereka untuk berekspresi terampas,
hal ini berbeda dengan anak anak diluar jeruji besi tahanan yang memiliki kebebasan
untuk berekspresi dan menjalankan pendidikan sebagaimana layaknya anak normal
seusianya. Faktor-faktor yang melatarbelakangi mereka terdiri dari faktor internal dan
faktor eksternal, adapun beberapa faktor internal diantaranya adalah sikap mental
yang tidak Sehat dari anggota geng motor, ketidakharmonisan dalam keluarga,
pelampiasan rasa kecewa, dorongan kebutuhan ekonomi, proses belajar yang

* Artikel ini hasil penelitian hibah LBH Cirebon 2013, dengan No.003/LBH-Cirebon/PBH/VII/2013 
menyimpang, kurangnya perhatian dan kasih sayang serta rendahnya tingkat pendidikan diantara mereka sedangkan faktor eksternal yaitu perlunya aparat penegak hukum untuk senantiasa melakukan tindakan preventif dalam menangani perkara geng motor dan partisipasi masyarakat di lingkungannya agar sigap melakukan tindakan preventif juga.

Kunci : Problematika, Geng, Motor, Sosiologis

\section{Pendahuluan}

Geng motor diartikulasikan sebagai sebuah kelompok yang terdiri dari beberapa anggota, memiliki program dan kepengurusan yang terorganisir serta memiliki konotasi yang negatif dalam perilakunya seperti berkelahi, merampas bahkan membunuh. Fenomena geng motor muncul dari metamorfosa dan dinamika sosial akibat moderenisasi yang tidak terbendung secara baik, muncul dari kegelisahan-kegelisahan akibat kurangnya kasih sayang dan perhatian keluarga. Sehingga keberadaan anggota di dalam geng (kelompok tertentu) merasa terlindungi, mendapat perhatian dari rekan-rekannya. Secara umum yang menarik perhatian kita adalah geng motor dan geng geng lainya yang merupakan kumpulan anak anak; contoh kasus yang masih hangat di telinga kita adalah keberutalan geng perempuan SMU dan geng motor. Keberadaan geng motor di Cirebon akhir-akhir ini sangat menghawatirkan kita semua, beberapa tindakan anarkis yang melanggar hukum sudah sering kali dilakukan seperti contoh kasus di berikut ini :

1. Pada tanggal 29 maret 2009 geng motor telah melakukan penganiyayaan terhadap Muhamad Nur Habibi, 15 tahun warga GSP serta penganiyayaan dengan cara membacok terhadap Muhamad Toto Tohir , 19 tahun warga desa bode lor, kec.plumbon dia dianiyaya saat melintas di jl.pangeran drajat.

2. Pada tanggal 24 April 2009 geng motor mengeroyok dan menusuk seseorang mahasiswa bernama Randi Aditiya Permana, 21 tahun warga ciperna kab.cirebon

3. Pada tanggal 26 April 2009 geng motor telah melakukan pelemparan batu yang menyebabkan luka-luka terhadap anggota polresta yaitu Bripda Encep dan Bripda Latif.

4. Pada tanggal 20 juni 2009 sekitar 20 geng motor menyerbu dan merusak konter HP di jl.pramuka harjamukti milik bapak Abdul Halid, 23 tahun. 
5. Pada tanggal 12 juli 2009, geng motor melempari satpam BRI Syariah, M Hardi Purwanto, 38 tahun hingga tewas.

Contoh diatas merupakan sebagian contoh yang bisa menjadikan kita semua terpaku, resah dan bahkan sedih melihat tindakan tindakan anti kemanusiaan dan pelanggaran hukum tentunya ini harus menjadi perhatian semua pihak dalam melihat fenomena diatas, kebijakan yang tepat dalam menangani masalah ini harus diformulasikan dari berbagai pandangan dan teori teori yang bisa dipertanggungjawabkan kebenaranya dalam membangun moralitas dan integritas masa depan generasi muda bangsa Indonesia. Dalam perspektif hukum keberadaan geng diatur dalam konstitusi kita yaitu Undang undang Dasar 1945 pasal 28 tentang kebebasan berserikat dan berkumpul yang termasuk dalam hak asasi manusia, adapun ketika mereka melakukan aksi-aksi keberutalan yang melanggar hukum pidana maka kepada mereka akan diberlakukan hukum pidana (KUHP) namun apabila tindakan kriminal tersebut dilakukan oleh anak anak maka kepada mereka diberlakukan hukum pidana anak hal ini sesuai dengan pengertian anak menurut uu perlindungan anak. ${ }^{1}$ dan akan diadili sesuai dengan uu no. tahun 1997 tentang pengadilan anak. Sedangkan payung hukum dalam melindungi keberadaan anak tersebut adalah uu no 23 tahun 2002 tentang perlindungan anak. Selain itu juga perlu diketahui adanya faktor yang tepat dalam melihat tindakan kriminalitas yang menurut data diatas bayak dilakukan oleh tindakan geng motor di kota cirebon kemudian perlu diketahui tentang ponis yang diputuskan oleh majlis hakim kaitanya dengan tindakan terdakwa tindak pidana yang dilakukan oleh geng motor serta upaya pendidikan di permasyarakatan terhadap para pelaku kriminal geng motor tersebut.

\section{Perumusan Masalah}

\footnotetext{
${ }^{1}$ Dalam UU perlindungan anak dijelaskan pada pasal 1 ayat (1) bahwa anak adalah seseorang yang belum berusia 18 tahun dan termasuk anak yang masih dalam kandungan sedangkan pada ayat (2) dijelaskan tentang perlindungan anak yang mengartikan segala kegiatan untuk menjamin dan melindungi anak dan hak-haknya agar dapat hidup,tumbuh,berkembang dan berpartisifasi secara optimal sesuai dengan harkat dan martabat kemanusiaan, serta mendapatkan perlindungan dan diskriminasi
} 
Dengan berlatarbelakang tersebut di atas sehingga menimbulkan masalahmasalah, yang harus dibahas di antaranya adalah:

1. Bagaimana problemantika hukum geng motor di kabupaten kuningan?

2. Bagaimana faktor faktor yang mempengaruhi tindakan kriminalitas geng motor di kabupaten kuningan ?

\section{Metode Penelitian}

Metode pendekatan yang digunakan adalah yuridis normatif, yaitu menganalisa permasalahan dari sudut pandang atau menurut ketentuan hukum atau peraturan hukum yang berlaku dan ada keterkaitan dengan masalah penelitian ini. Dalam penelitian ini akan digali bagaimana proses, dan kendala yang dihadapi dalam memecahkan probelemantika hukum geng motor, disamping itu peneliti juga berupaya untuk mencari faktor faktor yang mempengaruhi tindakan kriminalitas yang dilakukan oleh geng motor dikota cirebon, metode deskriftif kualitatif dipilih dalam penelitian ini karena lebih sistematis dan faktual dalam menggambarkan permasalahan mengenai situasi maslah yang akan dijawab dalam penelitian ini. Dengan demikian melalui penelitian dengan metode deskriptif kualitatif akan diperoleh gambaran tetang problemantika hukum serta faktor yang mempengaruhi tindakan kriminalitas geng motor dikota cirebon. Sugiono (1999,h,7), mengatakan bahwa : Penelitian deskriptif adalah, penelitian yang dilakukan terhadap variable mandiri, yaitu tanpa membuat perbandingan atau menghubungkanya dengan variable lain. Suatu penelitian yang berusaha untuk menjawab pertanyaan, seperti seberapa besar produktifitas lembaga, seberapa baik kepemimpinan, etod kerja dan prestasi kerja karyawan suatu lembaga. Pengertian lain yang berhubungan dengan pernyataan diatas adalah pendapat Moleong Penelitian deskriptif adalah, data yang dikumpulkan berupa kata kata, gambar, dan bukan angka-angka. Hal ini disebabkan oleh adanya penerapan metode kualitatif. Selain itu semua yang dikumpulkan kemungkinan menjadi kunci terhadap apa yang sudah diteliti. Dengan demikian, laporan penelitian akan berisi kutipan-kutipan data untuk memberi gambaran penyajian laporan tersebut. Data data tersebut mungkin berasal dari naskah wawancara, catatan lapangan, memo 
dan dokumen resmi lainya. Sebagaimana dikemukakan oleh Usman dan Akbar (1998,h.4) menyatakan bahwa, penelitian deskriptif bermaksud membuat penyadaran secara sistematis, faktual dan akurat mengenai fakta-fakta dan sifat populasi tertentu. Dari pengertian diatas, penelitian bertujuan untuk membuat gambaran secara deskriptif dan sistematis tentang problematika hukum dan faktor yang mempengaruhi tindakan kriminalitas geng motor dikota cirebon.

\section{Sumber Data}

Sumber data dalam penelitian ini adalah data sekunder. Menurut Soeryono Soekanto, data data sekunder dalam penelitian ini merupakan data dalam keadaan siap terbuat dan telah terbentuk dan diisi oleh peneliti terdahulu. ${ }^{2}$ Sumber data sekunder ini terdiri dari sumber hukum primer, sumber hukum sekunder dan sumber hukum tersier yaitu sebagai berikut :

a. Bahan hukum primer, yaitu bahan hukum yang mengikat, yakni sebagai berikut :

1) Declaration of Human Right 1948 (Deklerasi hak asasi manusia)

2) Undang undang Dasar 1945;

3) Undang undang perlindungan anak

4) Undang undang pengadilan anak

5) Kitab undang undang hukum pidana

6) Dan peraturan perundang undangan lainya yang berhubungan dengan permasalahan penelitian.

b. Bahan hukum sekunder, yaitu bahan hukum yang memberikan penjelasan mengenai bahan hukum primer, seperti : Rancangan Undang-undang, hasil hasil penelitian, karya dari kalangan pakar hukum dan sebagainya

c. Bahan hukum tersier atau bahan hukum penunjang, mencakup :

1) Bahan bahan yang memberi petunjuk petunjuk maupun penjelasan terhadap bahan hukum primer dan sekunder. Contohnya Kamus, Ensiklopedi, diktat, jurnal dll

\footnotetext{
${ }^{2}$ Soerjono Soekanto, Pengantar Penelitian Hukum, Jakarta: UI Press,1996, halaman.12
} 
2) Bahan bahan primer, sekunder dan tersier (penunjang) diluar bidang hukum, misalnya yang berasal dari bidang sosiologi, filsafat, fisikologi dan lain sebagainya, yang dapat dipergunakan untuk melengkapi atau menunjang data penelitian.

\section{Tekhnik Pengumpulan Data}

Alat pengumpulan data yang dipergunakan dalam penelitian ini adalah study kepustakaan dan wawancara, yakni mengkaji berbagai peraturan perundang undangan dan literature yang berhubungan dengan permasalahan penelitian serta bertanya kepada pihak pihak yang mengetahui data data tentang penelitian diatas.

\section{Analisa Data}

Bahwa data data yang telah dikumpulkan dari berbagai sumber dianalisa secara deskriptif kualitatif, yaitu menganalisa hasil penelitian kedalam bentuk bentuk penggambaran yang berupa uraian kalimat. Berdasarkan analisa yang dilakukan akan dirumuskan simpulan simpulan yang disajikan dalam bentuk uraian kalimat secara jelas dan rinci.

\section{Tinjuan Pustaka}

Fenomena geng motor menjadi cukup menarik untuk diteliti ketika banyak sekali tindakan tindakan brutal, tidak manusiawi bahkan melanggar koridor hukum positif yang hidup dalam system hukum kita. Dalam pandangan awam geng motor selalu berkonotasi negatife hal ini terjadi karena banyak tindakan tindakan asusila bahkan tidak manusiawi yang dilakukan oleh geng motor, padahal dalam kenyataan sebenarnya ada banyak juga geng motor yang justru memilki kegiatan yang positif seperti melakukan bakti sosial, santunan serta kegitan kegiatan konstruktif lainya. Keberadaan geng motor yang memilki citra negatif (brutal) atau yang senantiasa melakukan tindakan kriminal perlu dianalisa dari teori teori atau ilmu ilmu yang relevan seperti psikologi, sosiologi, kriminologi serta system hukum positif kita secara umum hal ini penting dalam rangka mencari solusi tepat untuk mengatasi tindakan geng motor yang cukup meresahkan kita semua. Dalam pandangan sosiologi 
hukum geng motor merupakan prilaku sosial sedangkanprilaku sosial terbagi dalam dua klasifikasi yaitu; prilaku yang menyimpang serta prilaku yang tidak menyimpang, sedangkan dalam menggambarkan tentang geng motor yang melakukan tindakan kriminalitas atau tindakan brutal masuk dalam klasifikasi tindakan yang menyimpan, adapun pengertian prilaku menyimpang menurut beberapa ahli adalah sebagai berikut, yaitu ${ }^{3}$ :

a. Robert M.Z. Lawang yaitu Penyimpangan adalah tindakan yang menyimpang dari norma-norma yang berlaku dalam suatu sistem sosial dan menimbulkan usaha dari pihak berwenang untuk memperbaiki perilaku yang menyimpang atau abnormal tersebut.

b. James Vander Zanden yaitu Penyimpangan merupakan prerilaku yang oleh sejumlah besar orang dianggap sebagai hal yang tercela dan diluar batas toleransi.

c. Kartini Kartono yaitu Penyimpangan merupakan tingkah laku yang menyimpang dari ciri-ciri karakteristik rata-rata dari rakyat kebanyakan.

Dari pengertian diatas dapat di simpulkan bahwa prilaku sosial yang menyimpang adalah suatu perilaku yang diekspresikan oleh seorang atau beberapa orang yang secara disadari atau tidak disadari, tidak menyesuaikan diri dengan norma yang berlaku dan telah diterima oleh sebagian besar anggota masyarakat. Dengan kata lain, semua bentuk perilaku yang tidak sesuai dengan norma dinamakan perilaku menyimpang, maka dapat di artikulasikan pula bahwa geng motor yang menyimpang adalah prilaku yang diekspresikan oleh anggota geng motor secara disadari atau tidak disadari, tidak menyesuaikan dengan norma norma yang berlaku yaitu norma agama, norma kesopanan, norma kesusilaan serta norma hukum yang berlaku dimasyarakat dan sudah menjadi kontrak sosial (social of contrac).

Prilaku sosial dalam kontek penyimpangan sosial dapat dilihat dalam teorinya yaitu sebagai berikut ${ }^{4}$;

\section{a. Teori Differential Association}

\footnotetext{
${ }^{3}$ Rianto Adi : Diktat Sosiologi Hukum, Program Megister Hukum, Untag, Jakarta, 2009 Halaman 23

${ }^{4}$ Ibid, Halaman 45
} 
Terori ini diciptakan oleh Edwin H. Sutherland yang berpendapat bahwa penyimpangan bersumber pada pergaulan yang berbeda. Penyimpangan dipelajari melalui proses alih budaya. Contohnya : proses menghisap ganja dan perilaku homoseksual.

\section{b. Teori Labelling}

Teori ini dipelopori oleh Edwin M. Lemerd yang berpendapat bahwa seseorang yang telah melakukan penyimpangan pada tahap primer (pertama) lalu oleh masyarakat sudah diberikan cap sebagai penyimpang, maka orang tersebut terdorong untuk melakukan penyimpangan sekunder (tahap lanjut) dengan alasan "kepalang tanggung". Contohnya : seorang ayah pernah sekali mencuri dengan alasan kebutuhan, tetapi kemudian oleh masyarakat dijuluki pencuri, maka ia akan terdorong menjadi penjahat bahkan dapat menjadi perampok.

\section{c. Teori Merton}

Teori ini dikemukakan oleh Robert K. Merton, yaitu perilaku penyimpangan merupakan bentuk dari adaptasi terhadap situasi tertentu. Merto mengidentifikasikan lima cara adaptasi, yaitu sebagai berikut :

1.) Komformitas, yaitu perilaku mengikuti tujuan dan cara yang ditentukan masyarakat untuk mencapai tujuan tersebut atau cara konvensional dan melembaga.

2.) Inovasi, yaitu perilaku mengikuti tujuan yang telah ditentukan oleh masyarakat, tetapi memakai cara yang dilarang oleh masyarakat.

3.) Ritualisme, yaitu perilaku yang telah meninggalkan tujuan budaya, tetapi masih tetap berpegang pada cara-cara yang telah digariskan oleh masyarakat. Ritual (upacara) masih diselenggarakan, tetapi maknanya telah hilang.

4.) Retretism, yaitu perilaku yang meninggalkan, baik tujuan konvesional maupun cara pencapaiannya. Contohnya : pecandu obat bius, pemabuk, gelandangan, dan orang gagal lainnya. 
5.) Rebellion, yaitu penarikan diri dari tujuan dan cara-cara konvensional yang disertai dengan upaya untuk melembagakan tujuan dan cara baru. Contohnya : para reformator agama dan GAM (Gerakan Aceh Medeka)

\section{d. Teori Fungsi}

Teori ini dikemukakan oleh Emile Durkheim bahwa kesadaran moral dari semua masyarakat adalah karena faktor keturunan, perbedaan lingkungan fisik, dan lingkungan sosial. Jadi, kejahatan akan selalu ada karena orang selalu ada yang berwatak jahat. Bahkan, ia berpendapat bahwa kejahatan itu perlu agar moralitas dan hukum dapat berkembang dengan normal. Menurut teori prilaku penyimpangan diatas dapat dianalisis bahwa tindakan kriminalitas bahkan brutalitas diatas sangat relevan dengan teori teori diatas tinggal bagaimana upaya untuk mencari faktor faktor yang penyebab tindakan brutal atau penyimapangan tersebut bisa terjadi selanjutnya adalah bagaimana mencari format tepat dalam mengendalikan geng motor untuk senantiasa menghilangkan tindakan tindakan penyimpangan selanjutnya bahkan kedepan geng motor menjadi corong perubahan generasi muda kearah lebih baik bahkan mungkin bisa jadi anggota geng motor di kota cirebon kedepan akan menjadi embrio atlit atlit balap Indonesia.

\section{Pengertian Geng Motor}

Ada banyak istilah tentang namun kaitanya dengan penulisan penelitian ini penulis konsen tentang geng motor, menurut hemat penulis geng motor adalah sekumpulan anak-anak atau orang-orang yang terorganisir kedalam satu kelompok geng memilki motor, pimpinan yaitu sebagai pimpinan geng motor. Sebagai layaknya organisasi maka geng motor masuk dalam klasifikasi organisasi kader hal ini dikarenakan pada perekrutan anggotanya bersifat tertutup dengan cara-cara yang kalau kita pernah lihat di media-media proses perekrutanya sangat tidak manusiawi. Pengertian diatas berbeda dengan pengertian dari club motor yang memilki variasi terhadap model dan bentuk motor kemudian secara program lebih banyak sisi sosial kemasyarakatanya, mengedepankan hubungan emosional antar sesama anggotanya. 
Biasanya organisasi club lebih bersifat terbuka untuk umum hanya saja kita untuk masuk club tersebut harus memilki kedaraan bermotor seperti yang diinginkan oleh club motor tersebut, contoh untuk masuk club tiger kita harus memilki motor tiger terlebih dahulu.

\section{Geng Motor Sebagai Prilaku Sosial}

motor sebagai prilaku sosial maksudnya adalah bahwa keberadaan geng motor selarah dengan dinamika dan perubahan sosial masyarakat, muncul dari perubahan industrialisasi di Indonesia hal ini terwujud dari perkembangan industrialisasi industri motor, dalam melihat fenomena perubahan sosial ini terdapat dua bnetuk prilaku sosial yang akan diuraikan satu persatu, yaitu ; prilaku sosial dan pengendalian sosial. Penjabran tentang dua betuk prilaku sosial dimaksud adalah untuk mendeskripsikan tentang geng motor sebagai sebuah bentuk penyimpangan sosial yang harus dilihat dalam teori, pandangan ahli, jenis dan bentuk penyimpangannya serta gejala gejala dari penyimpangan dimaksud sedangkan pengendalian sosial lebih menitik beratkan pada aspek pencarian metode atau cara dalam menyelesaikan fenomena prilaku sosial diamaksud, in menjadi poin dalam melihat dan merekomendasikan hal tepat untuk mencari jawaban tepat terkait maslah geng motor yang makin hari makin menghawatirkan kita semua. Keberadaan gengmotor dikota cirebon memberi warna tersendiri dalam hubunganya dengan aspek dinamika sosial kemasarakatan yang ada, perlunya kebijakan terhadap penyelesaian kebrutalan dan tindakan anarkis yang bisa dikeluarkan oleh lembaga-lembaga kompeten akan menjadi model akurat dalam penyelesaian fenomena tersebut. Kebrutalan tindakan geng motor di kota cirebon tidak lah datang begitu saja ini merupakan sebuah gejala turunan dari pesatnya informasi dan ketidak teraturan system dan formasi sosial, adanya geng motor di kota cirebon merupakan limpahan geng dari kota-kota besar seperti Jakarta, bandung karena secara organisasional organisaisi geng sebagai organisai terpusat.

\section{Prilaku Menyimpang}


Geng motor yang akhir-akhir ini cukup banyak mewarnai berita dimedia masa baik elektronik maupun media cetak, sangat menarik sekali bagi penulis untuk menguraikanya dalam sebuah penelitian yang barangkali menjadi masukan yang berharga dalam rangka memberikan kotribusinya terhadap strategi prepentif dalam mengatasi prilaku geng motor yang menyimpang. Geng motor sebagai perilaku menyimpang dapat didefinisikan sebagai suatu perilaku yang diekspresikan oleh seorang atau beberapa orang anggota geng motor yang secara disadari atau tidak disadari, tidak menyesuaikan diri dengan norma yang berlaku dan telah diterima oleh sebagian besar anggota masyarakat. Dengan kata lain, semua bentuk perilaku yang tidak sesuai dengan norma dinamakan perilaku menyimpang. Dan dalam hal ini muncul geng motor sebagai fenomena sosial yang secara subtantif sebenarnya tidak semua geng motor memilki prilaku yang menyimpang banyak diantara geng motor yang justri memilki program program sosial kemasyarakatan dan program peningkatan kualitas anggota melalui pelatihan otomotif dan kegiatan yang bermanfaat lainya namun bisanya geng motor yang berbuat demikian seperti halnya diatas dinamakan club motor. Menurut pendapat beberapa tokoh mengenai perilaku menyimpang.

\section{Robert M.Z. Lawang}

Penyimpangan adalah tindakan yang menyimpang dari norma-norma yang berlaku dalam suatu sistem sosial dan menimbulkan usaha dari pihak berwenang untuk memperbaiki perilaku yang menyimpang atau abnormal tersebut.

2. James Vander Zanden

Penyimpangan merupakan prerilaku yang oleh sejumlah besar orang dianggap sebagai hal yang tercela dan diluar batas toleransi.

3. Kartini Kartono Penyimpangan merupakan tingkah laku yang menyimpang dari ciri-ciri karakteristik rata-rata dari rakyat kebanyakan.

Dari pengertian tokoh diatas jelas bahwa geng motor dapat diklasifikasikan sebagai tindakan yang menyimpang hal ini senada dengan pengertian yang diuraiakan para ahli diatas yang secara umum dapat disimpulkan bahwa prilaku menyimpang adalah sebagai berikut; sebuah tindakan tindakan atau tungkah laku yang menyimpang dari 
norma-norma dan cirri cirri karakteristik rata-rata dari rakyat kebanyakan. Dibawah ini akan diuraikan tentang teori penyimpangan sosial, bentuk bentuk penyimapangan sosial, sifat-sifat prilaku penyimpangan sosial serta contoh-contoh terkait prilaku penyimpangan sosial yang akan coba dibenturkan pada keberadaan geng motor di kota cirebon, hal ini dimaksudkan agar dalam penulisan penelitian ini bisa mengklasifikasikan keberadaan geng motor yang brutal dan anarkis termasuk dalam teori mana, adapun teori teori tersebut adalah ;

\section{Teori Penyimpanagan Sosial}

\section{Teori Merton;}

a. Teori ini dikemukakan oleh Robert K. Merton, yaitu perilaku penyimpangan merupakan bentuk dari adaptasi terhadap situasi tertentu. Merto mengidentifikasikan lima cara adaptasi, yaitu sebagai berikut :

b. Komformitas, yaitu perilaku mengikuti tujuan dan cara yang ditentukan masyarakat untuk mencapai tujuan tersebut atau cara konvensional dan melembaga.

c. Inovasi, yaitu perilaku mengikuti tujuan yang telah ditentukan oleh masyarakat, tetapi memakai cara yang dilarang oleh masyarakat.

d. Ritualisme, yaitu perilaku yang telah meninggalkan tujuan budaya, tetapi masih tetap berpegang pada cara-cara yang telah digariskan oleh masyarakat. Ritual (upacara) masih diselenggarakan, tetapi maknanya telah hilang.

e. Retretism, yaitu perilaku yang meninggalkan, baik tujuan konvesional maupun cara pencapaiannya. Contohnya : pecandu obat bius, pemabuk, gelandangan, dan orang gagal lainnya.

f. Rebellion, yaitu penarikan diri dari tujuan dan cara-cara konvensional yang disertai dengan upaya untuk melembagakan tujuan dan cara baru. Contohnya : para reformator agama dan GAM (Gerakan Aceh Medeka) 


\section{Teori Fungsi;}

Teori ini dikemukakan oleh Emile Durkheim bahwa kesadaran moral dari semua masyarakat adalah karena faktor keturunan, perbedaan lingkungan fisik, dan lingkungan sosial. Jadi, kejahatan akan selalu ada karena orang selalu ada yang berwatak jahat. Bahkan, ia berpendapat bahwa kejahatan itu perlu agar moralitas dan hukum dapat berkembang dengan normal.

\section{Bentuk-Bentuk Perilaku Menyimpang.}

1) Penyimpangan Primer Adalah penyimpangan yang bersifat temporer atau sementara dan hanya menguasai sebagian kecil kehidupan seseorang. Ciri-ciri penyimpangan primer antara lain, yaitu : bersifat sementara, gaya hidupnya tidak didominasi oleh perilaku menyimpang, dan masyarakat masih mentolerir/menerima. Contohnya : misalnya pegawai kerja membolos kerja, siswa yang membolos atau mencontek saat ujian, dan melanggar peraturan lalu lintas.

2) Penyimpangan Sekunder Adalah perbuatan yang dilakukan secara khas dengan memperlihatkan perilaku menyimpang. Ciri-ciri penyimpangan sekunder, yaitu : gaya hidupnya didominasi oleh perilaku menyimpang dan masyarakat tidak bisa mentolerir perilaku penyimpangan tersebut. Contohnya : pembunuhan, perjudian, perampokan, dan pemerkosaan

3) Penyimpangan Individu Adalah penyimpangan yang dilakukan oleh seorang individu dengan melakukan tindakan-tindakan yang menyimpang dari normanorma yang berlaku. Contohnya : pencurian yang dilakukan sendiri.

4) Penyimpangan Kelompok Adalah penyimpangan yang dilakukan secara berkelompok dengan melakukan tindakan-tindakan yang menyimpang dari norma-norma masyarakat yang berlaku. Contonya : geng kejahatan, mafia, gengster.

5) Penyimpangan Situasional Penyimpangan jenis ini disebabkan oleh pengaruh bermacam-macam kekuatan situasional/sosial di luar individu dan memaksa individu tersebut untuk berbuat menyimpang. Contohnya : seorang suami yang terpaksa mencuri karena melihat anak dan istrinya yang kelaparan 
6) Penyimpangan Sistematik Adalah suatu sistem tingkah laku yang disertai organisasi sosial khusus, status formal, peranan-peranan, nilai-nilai, normanorma, dan moral tertentu yang semuanya berbeda dengan situsai umum. Segala pikiran dan perbuatan yang menyimpang itu kemudian dibenarkan oleh semua anggota masyarakat.

\section{Sifat-Sifat Perilaku Menyimpang}

a) Penyimpangan Positif Adalah penyimpangan yang mempunyai dampak positif karena mengandung unsur inovatif, kreatif, dan memperkaya alternatif. Jadi penyimpangan positif merupakan penyimpangan yang terarah pada nilai-nilai sosial yang didambakan, meskipun cara yang dilakukan tampaknya menyimpang dari norma yang berlaku. Contohnya : seorang ibu rumah tangga dengan terpaksa harus menjadi sopir taksi karena desakan ekonomi.

b) Penyimpangan Negatif Adalah penyimpangan yang cenderung bertindak ke arah nilai-nilai sosial yang dipandang rendah dan berakibat buruk. Dalam penyimpangan negatif, tindakan yang dilakukan akan dicela oleh masyarakat dan pelakunya tidak dapat ditolerir oleh masyarakat. Contohnya : pembunuhan dan pemerkosaan.

\section{Contoh Perilaku Menyimpang}

1. Tindakan Kriminal dan Kejahatan ; Kriminalitas bukan bawaan sejak lahir, bukan pula warisan biologis. Tindakan kriminal dapat dilakukan secara sadar melalui perencanaan dan ditujukan untuk maksud tertentu. Akan tetapi, ada pula yang dilakukan secara tidak sadar.

2. Kenakalan Anak (Juvenile Delinquency) ; Adalah semua perbuatan penyelewengan norma-norma kelompok tertentu yang menimbulkan keonaran dalam masyarakat yang dilakukan oleh anak muda. Secara fenomenologis, gejala kenakalan anak muda atau remaja ini tampak dalam masa pubertas. Karena pada masa tersebut jiwanya masih dalam keadaan labil sehingga mudah terpengaruh oleh lingkungan pergaulan yang negatif. 
3. Penyimpangan Seksual ; Adalah aktivitas seksual yang ditempuh seseorang untuk mendapatkan kenikmatan seksual tidak sewajarnya. Bentuk-bentuknya antara lain sebagai berikut :

4. Homoseksual, yaitu tertarik pada seseorang yang berjenis kelamin sama.

5. Transeksual, yaitu cenderung mengubah karakteristik seksualnya.

6. Sadomasokisme, yaitu kepuasan seksual yang diperoleh bila melakukan hubungan seksual dengan terlebih dahulu menyiksa atau menyakiti pasangannya.

7. Alkoholisme ; Alkohol dapat disebut sebagai racun protoplasmik yang mempunyai efek depresan pada sistem syaraf sehingga orang yang mengonsumsi minuman beralkohol secara berlebihan akan kehilangan kemampuan untuk mengendalikan diri, baik secara fisik, psikologis, maupun sosial. Itulah sebabnya seorang pemabuk sering menimbulkan keonaran atau kejahatan.

8. Penyalahgunaan Narkotika ; Penyalahgunaan narkoba dapat menyebabkan pikiran menjadi tidak rasional dan sulit membedakan perbuatan baik dan buruk.

9. Hubungan Seksual Sebelum Menikah ; Dalam lingkungan masyarakat yang bernorma, hubungan seksual sebelum atau diluar nikah tidak dapat dibenarkan, khususnya norma agama, sosial, maupun moral. Hubungan seksual dianggap sah apabila sudah menikah.

10. Sadisme Terhadap Anak ; Bentuk-bentuk penganiayaan emosional terhadap anak adalah :

11. Rejecting, yaitu orang tua menunjukan perilaku menolak dan tidak suka atas keberadaan anak.

12. Ignoring, yaitu orang tua yang tidak mau menunjukan kedekatan dengan anaknya karena tidak menyukainya.

13. Terorizing, yaitu orang tua yang mengkritik, secara tidak proposional, menghukum, mengolok-olok dan mengharapkan anak memiliki kemampuan seperti yang diinginkan orang tuanya.

14. Isolating, yaitu orang tua yang membatasi secara berlebihan aktivitas anak dengan teman-teman sebayanya. 
15. Corrupting, yaitu orang tua yang mengajarkan yang salah (melanggar norma) pada anaknya.

Dari paparan diatas dapat ditarik kesimpulan bahwa geng motor yang melakukan tindakan kriminalitas dan brutal termasuk dalam bentuk penyimpangan kelompok hal ini dikarenakan tindakan tindakan yang menyimpang itu dilakukan oleh kelompok geng motor, sedangkan kalau dilihat dari segi sifatnya keberadaan geng motor dikota cirebon bisa diklasifikasikan sebagai prilaku penyimpangan negatif karena perbuatan mereka selalu berakibat korban dan atau kerusakan yang menimbulkan penilaian tercela dari masyarakat. Sedangkan dilihat dari contohnya tindakan geng motor menurut hemat penulis bisa dikatagorikan sebagai bentuk kenakalan anak anak hal ini disebabkan karena pelaku dan anggota geng motor merupakan anak-anak usia diabawah 18 Tahun, yang menurut aturan hukum masuk dalam klasifikasi pidana anak.

\section{Pengendalian Sosial}

Beberapa pengertian tentang pengendalian sosial menurut para ahli diantaranya sebagai berikut, yaitu ;

1. Berger mendefinisikan Pengendalian sosial adalah cara yang digunakan untuk menertibkan anggota masyarakat yang membangkang.

2. Roucek mengartikan Pengendalian sosial adalah proses terencana maupun tidak tempat individu diajarkan, dibujuk, ataupun dipaksa untuk menyesuaikan diri pada kebiasaan dan nilai hidup kelompok.

Secara umum pengendalian dapat disimpulan sebagai upaya untuk mewujudkan kondisi seimbang didalam masyarakat. Dengan demikian tujuan pengendalian sosial adalah sebagai berikut :

1. Agar masyarakat mau mematuhi norma-norma sosial yang berlaku, baik dengan kesadaran sendiri maupun karena paksaan.

2. Agar dapat mewujudkan keserasian dan ketentraman dalam masyarakat.

3. Bagi orang yang melakukan penyimpangan diusahakan agar kembali mematuhi norma-norma yang berlaku. 
Prilaku geng motor sebagi prilaku sosial yang menyimpang dan memilki sifat yang negatif hal ini perlu adanya system pengendalian sosial agar prilaku dari geng motor tersebut tidak bersifat continuitas, maka hal tepat untuk mengilustrasikan proses penyelesaianya adalah pengendalian sosial sesuai dengan pengertianya dari para ahli yaitu sebagai cara untuk menertibkan masyarakat yang menyimpang terhadap norma-norma sosial yang hidup dimasyarakat, seperti norma agama, norma kesopanan, norma kesusilaan dan norma hukum, adapun fungsi-fungsi dari pengendalian sosial dalam rangka penertiban geng motor yang brutal dan anarkis adalah sebagai berikut ;

1. Mempertebal keyakinan geng motor tentang kebaikan norma.

2. Mengembangkan rasa malu atas dampak yang akan diterima jika geng motor melakuakn pelanggaran norma.

3. Mengembangkan rasa takut untuk melanggar peraturan dan norma karena pasti akan mendapatkan ganjaran dan sanksi.

4. Memberikan imbalan geng motor yang menaati norma.

5. Menciptakan sistem hukum dan norma sosial yang baik.

Dapat diperjelas bahwa fenomena geng motor dikota cirebon bisa diselesaikan aslah system penyelesaian yang dilakukan didapat dari ketetpatan pendekatan pendekatanya, perlu disampaikan pula bahwa terdapat jenis-jenis pengendalian sosial yang ada dan hidup di masyarakat kita serta sifat-sifat pengendalian sosial yang dapat digunakan dalam penyelesaian fenomena geng brutal dan anarkis di kota cirebon, yaitu;

\section{Pengendalian Sosial Formal}

Pengendalian sosial formal dijalankan melalui lembaga-lembaga formal yang ada di mesyarakat. Jenis lembaga-lembaganya adalah :

1. Lembaga Kepolisian

2. Lembaga Kejaksaan

3. Lembaga Pengadilan

4. Lembaga Adat 


\section{Pengendalian Sosial Nonformal}

Pengendalian sosial juga dilakukan oleh para pemuka masyarakat yang mempunyai pengaruh ataupun kharisma untuk mengatur berbagai kegiatan masyarakat. Tokoh-tokoh masyarakat ini merupakan panutan sekaligus pengendali yang dipatuhi oleh warga masyarakat yang lain. Dengan demikian, sistem ketertiban yang ada di dalam masyarakat tersebut sangat ditentukan oleh peranan tokoh-tokoh masyarakat. Adapun sifat-sifat pengendalian sosial yang bisa digunakan dalam pisau analisa dalam melihat tindakan kriminalitas keberadaan geng motor dikota cirebon adalah sebagai berikut, yaitu;

1. Pengendalian Social Preventif Yaitu usaha pengendalian sosial yang dilakukan sebelum terjadi pelanggaran. Contohnya : pemberian nasihat kepada anak untuk tidak ngebut di jalan raya supaya tidak terjadi kecelakaan.

2. Pengendalian Social Represif Yaitu pengendalian sosial yang dilakukan apabila telah terjadi pelanggaran dan supaya keadaan pulih seperti sedia kala. Contohnya : seseorang lalai untuk membayar hutang, kemudia diajukan ke pengadilan. Selanjutnya pengadilan menjatuhkan hukuman supaya ia membayar kembali hutang tersebut disertai dengan dendanya.

3. Pengendalian Social Gabungan Merupakan gabungan antara pengendalian preventif dan represif. Perpaduan antara kedua sifat pengendalian sosial ini ditujukan untuk mencagah terjadinya penyimpangan (preventif) sekaligus memulihkan kembali keadaan semula jika sudah terjadi penyimpangan (represif) sehingga suatu perilaku yang menyimpang tidak sempat merugikan pelaku yang bersangkutan ataupun orang lain. Contohnya : diperlakukan tugas piket di sekolah yang dimaksudkan untuk mengawasi dan mencegah siswa agar tidak bolos pada jam pelajaran (tindakan preventif). Meskipun pengawasan tersebut telah dilakukan, tetap saja terdapat siswa yang bolos, maka tindakan represif dapat dilakukan untuk mengembalikan penyimpangan itu ke keadaan normal dengan cara mengenakan sanksi atau hukuman kepada siswa tersebut sesuai dengan peraturan yang berlaku. 
4. Pengendalian Social Persuasif Dilakukan melalui pendekatan dan sosialisasi agar masyarakat mematuhi norma-norma yang ada. Pengendalian sosial ini dilakukan tanpa kekerasan.

5. Pengendalian Sosial Koersif Bersifat memaksa agar anggota masyarakat berperilaku sesuai dengan norma-norma yang ada dalam masyarakat.

6. Cakupan Pengendalian Sosial Ada 4 cakupan pengendalian sosial, yaitu :

a. Pengendalian sosial antar individu.

b. Pengendalian sosial individu terhadap kelompok.

c. Pengendalian sosial kelompok terhadap individu.

d. Pengendalian sosial kelompok dengan kelompok.

Berikut adalah cara yang bisa digunakan dalam pengendalian sosial terhadap keberadaan geng motor yang menyimpang dapat dilakukan dengan memberikan sanksi atau hukuman kepada si pelanggar. Sanksi atau hukuman yang dilakukan tersebut dapat berupa :

1. Fisik ; memberikan sanksi atau hukuman yang berhubungan dengan fisik. Contohnya : seorang murid dihukum berdiri di depan kelas oleh gurunya karena terlambat datang ke sekolah.

2. Psikologis ; memberikan sanksi atau hukuman yang berhubungan dengan psikologis atau perasaan. Contohnya : dimarahi, disindir, atau tidak dipedulikan.

3. Ekonomi ; memberikan sanksi atau hukuman yang berhubungan dengan ekonomi atau materi. Dapat berupa denda. Contohnya : seseorang yang ditilang polisi karena melanggar peraturan lalu lintas harus membayar denda.

\section{Pembahasan Tindakan Kriminalitas Geng Motor}

Tindakan kriminal secara umum dapat diartikan sebagai tindakan yang dilakukan oleh satu orang atau lebih (subyek hukum pidana) yang melakukan tindakan melanggar aturan aturan hukum positif yang ada misalnya KUHP ( kitab undang undang hukum pidana). Sedangkan Geng motor seperti telah diartikan diatas 
yaitu sebagi sekumpulan anak ankak yang terorganisir dalam sebuah klompok motor, jadi secara keseluruhan tindakan kriminalitas geng motor adalah sebuah tindakan pelanggaran hukum pidana baik umum maupun khusus yang dilakukan oleh sekelompok geng motor, sebenarnya teori tepatnya dalam memahami tindakan sebabsebab kriminalitas itu terjadi perlua adanya kajian kriminologi dalam memahami tindakan yang dilakukan sehinggga akan muncul ketepatan dan solusi tepat dalam membangun dan menyelesaikan problemantika geng motor di kota cirebon. Dalam melihat tindakan kriminalitas ilmu kriminologi akan sangat berperan dalam menganalisa sejauh mana sebab sebab tindakan kriminal itu dilakukan, hal tersebut senada dalam pengertian-pengertian yang coba diuraikan oleh Prof.Dr.H.Romli Atmasasmita,SH,LL.M tentang kriminologi yaitu';

1. Kriminologi merupakan study tentang tingkah laku manusia tidaklah berbeda dengan study tentang tingkah laku lainya yang bersifat nonkriminal.

2. Kriminologi merupakan ilmu yang bersifat inter dan multidisiplin, bukan ilmu yang bersifat monodisiplin.

3. Kriminologi berkembang sejalan dengan perkembangan ilmu pengetahuan lainya.

4. Perkembangan studi kejahatan telah membedakan antara kejahatan sebagai suatu tingkah laku dan pelaku kejahatan sebagai subjek perlakuan saran peradilan pidana.

Berdasarkan pada penjelasan diatas tentang kriminologi sebagai sebuah ilmu maka brutalitas tindakan gengmotor yang menyetuh pada pelanggaran hukum pidana, seperti contoh contoh yang terjadi dikota cirebon yang secara umum adalah tindak kekerasan baik dilakukan oleh satu anggota geng motor atau dilakukan bersama sama anggota geng, baik berupa kekerasan atau berupa pengrusakan adalah perlu dikaji dalam pandangaan kriminologi. Analisa Teori Kriminologi tentang kejahatan kekerasan. Mulyana W Kusumah (1988:22-33) telah memberikan deskripsi singkat mengenai kejahatan kekerasan selama priode 1980-1984. Dari deskripsi dimaksud diperoleh kesimpulan-kesimpulan sebagai berikut :

\footnotetext{
${ }^{5}$ Romli Atmasasmita, Teori dan Kapita Selekta Kriminologi,penerbit Refika Aditama, Bandung, 2007,hlm.12
} 
1. Mengenai jenis kejahatan dengan kekerasan, diidentifikasi terdapat 6 jenis yaitu : pencurian dengan kekerasan, pembunuhan, perkosaan, penculikan, pemerasan dan sebagainya

2. Jumlah kejadian dari keenam jenis kejahatan kekerasan tersebut menunjukan keadaan yang relatif meningkat sejak tahun 1980- sampai dengan tahun 1984

3. Model kejahatan dengan kekerasan yang menonjol adalah pencurian kendaraan bermotor, pemerasan serta penculikan.

4. Jumlah pelaku yang tidak memiliki pekerjaan ternyata dua kali lipat dari jumlah pelaku yang memilki pekerjaan.

5. Usia pelaku terbanyak bervariasi antara usia serendah rendahnya15 tahun dan setinggi tingginya 55 tahun,dengan catatan usia antara 15-24 merupakan mayoritas. $^{2}$

Menurut pendapat diatas ketika dikorelasikan dengan tindakan geng motor di kota cirebon tentang tindakan kriminal yang banyak dilakukan yaitu kejahatan dengan kekerasan, pengrusakan dan pembunuhan serta usia rata rata yang disebutkan diatas hampir menyerupai apa yang sudah dijelaskan terdahulu oleh Mulyana W Kusumah tentang teori kejahatan dengan kekerasan. Selain dari itu dalam perspektif teori kriminologi yang dapat dipergunakan untuk menganalisis model kejahatan dengan kekerasan di Indonesia adalah teori yang dikembangkan oleh Hoefnagels dalam bukunya “ The Other Side Of Criminoligy “, Hoefnagels dalam bukunya telah mengungkapkan bahwa para ahli kriminologi pada umumnya sering bertumpu pada teori kuasa kejahatan dan pelakunya, namun kurang memperhatiakan sisi lain dari suatu kejahatan. Ia menunjukan bahwa sisi lain dimaksud adalah aspek stigma dan seriusness. Lebih dari pada itu dalam analisa kriminologi akan dilihat tentang teori relevan yang menyebabkan mereka (geng motor) melakukan tindakan brutal yang mengarah tindakan kriminalitas, beberapa teori relevan dalam kriminologi kaitanya dengan faktor penyebab terjadinya kejahatan oleh geng motor yaitu ;

2 Kusumah, Mulyana W.1988, Kejahatan dan Penyimpangan : Suatu perspektif kriminologi, YLBHI,Jakarta 
Teori Asosiasi Diferensial ( Differential Association) yaitu Teori ini dikemukakan pertama kali oleh seorang sosiolog Amerika, E.H Sutherland, pada tahun 1934 dalam bukunya Principle Of Criminology. Menurut teori ini ada dua pandangan yaitu Systematic criminal behavior dan social disorganization, namun pada bakhirnya ia hanya konsentrasi terhadap teori konflik budaya (budaya kejahatan).

1. Teori Anomi adalah Teori ini dipopulerkan oleh Durkhaim (1897) menyatakan bahwa kejahtan berasal dari tiga kondisi yang menekan (stress), yaitu : (1) deregulasi kebutuhan atau anomi; (2) regulasi yang keterlaluan atau fatalisme; (3) kurangnya integrasi struktural atau egoisme.

2. Teori Kontrol Sosial adalah Pemunculan teori control sosial ini diakibatkan tiga ragam perkembangan dalam kriminologi, ketiga tagam perkembangan dimaksud adalah:

a. Pertama, adanya reaksi terhadap orientasi labeling dan konflik dan kembali kepada penyelidikan tentang tingkah laku kriminal. Kriminologi konservatif (sebagaimana teori ini berpijak) kurang menyukai kriminologi baru dan hendak kembali kepada subjek semula, yaitu : Penjahat.

b. Kedua, munculnya study tentang criminal justice sebagai suatu ilmu baru telah membawa pengaruh terhadap kriminologi menjadi lebih pragmatis dan berorientasi pada system.

c. Ketiga, teori control sosial telah dikaitkan dengan suatu tekhnik riset baru khususnya bagi tingkah laku anak remaja, yakni self report survey.

Perkembangan berikutnya selama tahun 1950-an, beberapa teoretisi telah menggunakan pendekatan teori control sosial terhadap kenakalan remaja, ada tiga poin terkait hal tersebut, yaitu ;

1. Kurangnya control internal yang wajar selama masa kanak-kanak

2. Hilangnya control tersebut

3. Tidak adanya norma-norma sosial atau konflik antara norma-norma dimaksud. adalah undang undang pengadilan anak.

\section{Upaya Pembinaan Geng Motor}


Upaya pembinaan geng motor dapat dilakukan melalui pembinaan secara kelompok (geng) dan secara individu (person). Keberadaan sebuah kelompok atau geng yang melakukan aktivitas kelompoknya dengan hal-hal yang menyimpang (brutalisme) merupakan akibat dari lemahnya daya kontrol keluaga (rumah), lingkungan (sekolah dan tempat-tempat aktivitas lainnya) terhadap aktivitas pergaulan anak-anak sehari-hari. Kekuatan (power) prilaku menyimpang kelompok berangkat dari akumulaasi prilaku-prilaku menyimpang pribadi yang sudah ada pada diri masing masing secara individu. Bentuk penyimpangan prilaku secara individu lahir dari berbagai hal yang mempengaruhi labilnya psikologi person sehingga kebanyakan anak yang mengalami hal tersebut, ditambah pula dipengaruhi oleh usia pada masa kanak-kanak yang bersifat labil maka hal ini yang mendorong person untuk mencari tempat yang mampu memberikan apa yang diinginkannya. Biasanya hal-hal yang mempengaruhi labilnya psikologis mereka secara person pada sebuah keluaraga dikarenakan: kurangnya kasih sayang orang tua; kurangnya perhatian orang tua; keberadaan ekonomi yang pas-pasan (cendrung berekonomi lemah); kebebasan berlebihan yang diberikan orang tua, dll. Melihat persoalan diatas maka upaya pembinaan secara kelompok (geng) dapat dilakukan dengan adanya perhatian yang intens dari keluarga terhadap prilaku bermain anak dan memantau teman-temannya (kelompok bermainnya), kemudian secara institusi pendidikan dimana mereka bersekolah dapat memberikan arahan disaat kegiatan ekstrakulikuler yang mereka lakukan dan pada kegiatan upacara sekolah yangmana kepala sekolah dan para guru dapat terus mengingatkan tentang prilaku menyimpang geng motor yang harus dihindari dan ketegasan sekolah memberikan hukuman untuk para siswa yang melakukan pelangaran sekolah dan hal ini dapat disampaikan disaat mereka menjadi pembina upacara sekolah, terakhir yaitu dari institusi keamanan (red-kepolisian) dapat mengontrol setiap kumpulan tongkrongan (red-geng motor) untuk melakukan pendekatan dan kemudian kelompok-kelompok ini dapat dijadikan kelompok binaan kepolisian sehingga segala aktivitas mereka dapat terkontrol oleh kepolisian. Kelompok -kelompok motor yang telah dibina ini dinamakan dengan Club Motor, keberadaan club motor tidak memberikan kontribusi keributan atau keberutalan di 
kota Cirebon hal ini dikarenakan mereka setiap satu bulan sekali mendapat pembinaan dari kepolisian.

Secara individu pembinaan dapat dilakukan dengan menjaga psikologis anak selalu dalam keadaan stabil sehingga ini akan sangat mungkin mampu untuk meminimalisir bahkan meniadakan prilaku menyimpang yang akan dapat terjadi atau menghinggapi anak-anak. Menurut Dr. Wagiati Soetodjo, SH, M.S, Hukum Pidana Anak, hal. 62, ada empat (4) lingkup yang mampu membangun psikologis mereka untuk tetap setabil secara berkesinambungan dalam rangka pembinaan, yaitu: 1). Keluarga; 2). Sekolah; 3). Masyarakat, dan 4). Agama

Keluarga adalah lembaga pendidikan yang pertama dan utama bagi seorang anak. Pembinaan Generasi Muda dimulai dengan membina kepribadian anak. Pendidikan yang diberi anak dari orang tua dalam kelurga, baik pendidikan yang dilakukan dengan sengaja maupun tidak disengaja akan menjadi bagian dari pribadinya. Jika bapak-ibunya baik, rukun dan menyayangi maka ia akan mendapat unsure-unsur positif dalam kepribadiannya, dan apabila orang tuanya beragama serta taat melaksanakan agama dalam kehidupan sehari-hari, maka anak mendapatkan pengalaman keagamaan yang menjadi unsur dalam kepribadiannya. Pemahaman orang tua terhadap perkembangan jiwa anak sangatlah penting dalam keluarga. Dengan pemahaman tersebut orang tua menciptakan suasana yang menyenangkan dan menumbuhkan kasih sayang, rasa aman, rasa sukses dan harga diri. Perlakuan dan pemahaman ini diperlukan anak mulai dari kecil, usia remaja bahkan usia dewasa. Pembinaan orang tua yang tidak memahami perkembangan jiwa dan kebutuhan anak, akan menyebabkan timbulnya rasa kurang puas, kesal, tertekan dan macam-macam perasaan negatif lainnya. Hal ini merupakan faktor negatif dalam perkembangan jiwa anak dan selanjutnya akan membentuk pribadi yang negatif pula.

Sekolah merupakan lembaga pendidikan formal, yang sedara teratur dan terencana melakukan pembinaan terhadap generasi muda. Fungsi sekolah tidak saja memberikan pengajaran dan pendidikan secara formal, akan tetapi sekolah dengan semua peraturan dan perangkatnya merupakan unsure Pembina bagi generasi muda. Artinya guru bagi murid tidak hanya sebagi pengajar tetapi juga sebagai contoh 
tauladanbagi anak didiknya. Semakin kecil umur anak didik semakin besar pengaruh guru dan sekolah bagi anak didiknya. Sikap guru dan sekolah bagi anak didiknya. Sikap guru, penampilan, tindakan dan cara hidupnya merupakan pengaruh yang sangat penting. Sedangkan bagi anak didik yang meningkat remaja disamping penampilan, kebijaksanaan dan kepribadian guru merupakan cara pendekatan yang terpenting karena dalam masa ini anak remaja mengalami perubahan cepat yang terjadi pada dirinya, menimbulkan kegoncangan emosi sehingga perasaannya amat peka dan tidak mudah menerima apa yang ia tidak mengerti. Bagi remaja usia lain (setingkat SMU) biasanya mereka telah berada pada tahap kematangan, pertumbuhan jasmani, intelegensia dan jiwa sosilanya sangat tinggi. Menghadapi mereka perlu dengan pengertian dan keramahtamahan. Artinya mereka tidak boleh dianggap remeh, dicela, diperintah secara kasar dan keras melainkan harus didekati dengan kelembutan serta mencoba memahami dan membantunya untuk mendapatkan keseimbangan jiwa. Remaja yang duduk di Perguruan Tinggi, dimana kegoncangan emosi telah semakan surut, mereka sangat peka terhadap masalah sosial dan sangat idealis sehinggamereka sangat mudah dipengaruhi oleh pimpinan atau tokoh-tokoh yang mereka kagumi. Konvergensi atau kontradiktif yang terjadi antara nilai-nilai dan kaidah yang diajarkan padanya dan apa yang dilihatnya dari masyarakat akan menggoncangkannya sehingga pendekatan dan pembinaan harus dilakukan dengan membukakan jalan dan pengertian dari semua masalahnya, tunjukan baik buruknya dengan penjelasan rasional dan yang paling penting dalam membina generasi muda ini adalah mendengarkan dan menghargai pendapatnya. Dengan demikian, remaja diajak dan dipersiapkan untuk menjadi seorang dewasa yang bertanggung jawab dan mampu mengatasi segala persoalan. Masyarakat Pada usia anak dan remaja, pengaruh lingkungan masyarakat terkadang lebih besar dari pada pengaruh keluarga, sebab saat ini merupakan masa pengembangan kepribadiannya, memerlukan pengakuan lingkungan, teman-teman dan masyarakat pada umumnya. Generasi muda biasanya amat besar perhatiannya terhadap persoalan masyarakat, karena pada usia tersebut mulai tumbuh idealisme (cendrung mengharapkan kesempurnaan). Seringkali mereka berjuang untuk membela yang lemah dan menderita, tetapi tidak jarang pula mereka 
yang terjerumus apabila tidak mampu menyerap dan menganalisa serta memilih yang baik. Untuk itu, pengembangan usaha-usaha pembinaan oleh setiap anggota masyarakt sebab lingkungan masyarakat dan keadaan-keadaannya akan mempengaruhi keperibadian generasi muda. Sikap, way of live dan cara hidup masyarakat, sadar atau tidak, sengaja ataupun tidak telah membina generasi muda. Apabila dalam masyarakat terdapat penyakit-penyakit sosial atau lingkungan yang buruk, hal ini membentuk generasi muda berprilaku buruk pula. Oleh karena itu adalah tanggung jawab setiap anggota masyarakat untuk membentuk generasi muda yang mampu mengemban amanat pembangunan Negara di masa datang. Agama akan memberikan pengalaman tertentu bagi anak-anak dan remaja. Ketaatan beribadah memberikan rasa tenang dan bahagia sebab hati dekat dengan Tuhan, sehingga agama akan mampu membentuk sikap pribadi yang positif bagi generasi muda, terutama dalam menghadapi masa percobaan (puber/adolenses). Di samping itu juga apabila remaja mengalami kegoncangan dan ketidaktenangan dalam rumah atau keluarganya, pengaruh ketaatan terhadap agama akan menjadi rem dan pengendali yang amat baik bagi sikap dan tindakan bagi generasi muda. Apabila remaja (generasi muda) pengalaman keagamaannya kurang sejak kecil, maka pada saat anak menanjak remaja ia akan labil dan bingung menghadapi kesulitan (persoalan) pribadinya, sehingga mudah terseret pada sikap dan tindakan-tindakan yang negatif. Kedua, pembinaan kelompok dapat pula dilakukan dengan mengunakan pendekatan empat (4) aspek diatas, dan juga terkait kelompok (geng) disini dapat dilakukan oleh institusi keamanan sepeti Kepolisian, dimana geng motor memiliki kaitan dengan institusi tersebut dalam hal ketertiban lalu lintas (pada saat melakukan aktivitas secara massal). Kepolisian dalam hal ini (Satlantas) dengan wewenang yang dimilikinya, mereka akan mampu mengontrol secara kelompok aktivitas geng tersebut. Ini dikarenakan setiap geng/kelompok motor wajib mendaftarkan lembaga nya. Setelah terdaftar polisi memiliki program-program pembinaan tersendiri, yang mana bertujuan supaya geng motor tersebut patuh terhadap aturan-aturan yang ada. Dan sudah pastinya ketika geng motor ini mampu melaksanakan aturan yang berlaku dengan otomatis keberutalan yang disebabkan/dilakukan oleh geng motor tidak akan 
terjadi. Dalam hemat penulis, jika model pembinaan secara individu dan kelompok ini dilaksanakan secara bersamaan in sangat memungkinkan dapat menciptakan suasana aman dan tentram dari keberutalan geng motor di kota cirebon.

Beberapa upaya yang bisa dilakukan sebagai upay dalam mengatasi geng motor di kota cirebon, upaya dimaksud dapat dilakukan secara eksternal dan internal. Upaya internal merupakan upaya yang dilakukan oleh komponen masyarakat di bawah koordinasi para pemukan adat dan masyarakat dan dapat dimulai dari pengendalian diri tiap-tiap individu. Sementara upaya eksternal bersifat lebih keras, tegas dan memaksa, dan pengendalian eksternal dilakukan oleh lembaga lembaga formal seperti kepolisian dan pengadilan.

Suatu ketertiban yang terwujud di dalam masyarakat sesungguhnya ditentukan oleh tiga komponen penting, yaitu sebagai berikut :

1. Norma-norma yang memadai dan sesuai dengan perkembangan masyarakat

2. Aparat penegak hukum yang konsisten secara ideologi dan mengambdikan dirinya dalam setiap upaya penegakan hukum.

3. Adanya kesadaran dari seluruh warga masyarakat untuk berlaku tertib.

Bentuk-bentuk nyata kejadian dalam masyarakat yang merupakan akibat langsung dari tidak berfungsinya lembaga-lembaga pengendalian sosial adalah sebagai berikut :

1. Tidak adanya kepastian hukum.

2. Kepentingan masyarakat sulit dipenuhi.

3. Sering terjadi konflik karena munculnya banyak perbedaan.

4. Munculnya komersialisasi hukum, jabatan, dan kekuasaan.

5. Munculnya sindikat-sindikat kejahatan yang mempunyai kepentingan khusus.

Media Pembentukan Perilaku Menyimpang terhadap geng motor di kabupaten kuningan adalah sebagai berikut :

a. Keluarga Pembentukan kepribadian seseorang untuk pertama kalinya akan berawal dari keluarga karena proses sosialisai yang dialami seorang individu untuk membentuk kepribadiannya itu berawal dari media sosialisasi ini. Keluarga 
merupakan faktor penentu bagi perkembangan atau pembentukan kepribadian seorang anak selanjutnya. Kepribadian anak akan cenderung positif jika ia dilahirkan di keluarga yang baik dan harmonis, dan sebaliknya akan cenderung negatif jika lahir dikeluarga yang kacau dan selalu terbebani dengan berbagai masalah.

b. Lingkungan Tempat Tinggal Lingkungan tempat tinggal juga dapat mempengaruhi kepribadian seorang individu dalam proses pembentukannya. Seorang individu yang tinggal dalam lingkungan yang baik (taat dalam melakukan ibadah, melakukan perbuatan yang baik dan positif) akan mempengaruhi kepribadiannya menjadi baik. Sebaliknya, bila seorang individu hidup dan tinggal di lingkungan yang buruk (suka melakukan tindakan kriminalitas) akan membentuk kepribadian yang buruk atau menyimpang.

c. Kelompok Bermain Adakalanya seorang individu juga mempunyai kelompok bermain atau pergaulan di luar lingkungan tempat tinggalnya tadi yang ia peroleh dari lingkungan sekolah atau di luar sekolah. Kelompok bermain atau pergaulan ini juga dapat mempengaruhi pembentukan kepribadian seorang individu. Jika ia memiliki kelompok bermain yang positif, suka belajar, dan melakukan perbuatan yang baik, maka perilakunya cenderung positif. Sebaliknya apabila individu memilih kelompok bermain yang negatif, maka pola perilaku dan kepribadiannya akan cenderung negatif. Karena itu kita harus pintar-pintar memilih teman untuk kita bergaul.

d. Media Massa Dapat disebut sebagai media sosialisasi yang dapat mempengaruhi kepribadian seseorang. Pemberitaan yang ada di media massa seperti surat kabar, televisi, atau internet dapat memicu maraknya perilaku menyimpang. Contohnya : tayangan yang berbau pornografi, pornoaksi, dan kekerasan dapat mempengaruhi perilaku seseorang.

\section{Faktor-faktor yang mempengaruhi tindakan kriminal genk motor}


Pada bab sebeumnya telah diuraikan tentang beberapa tindakan dan perlakuan geng motor yang menyimpang dari norma-norma sosial yang ada, hal ini menjadi satu keyakinan kita semua bahwa fenomena geng motor menjadi penting bagi kita semua untuk menyelesaikannya agat kedepan hal ini bisa dicegah perkembanganya dalam rangka kualitas generasi muda mendatang, pada bab ini akan diuraikan tentang faktor-faktor yang menjadi pemicu sebuah geng motor melakukan tindakan tindakan kriminal dan brutal hal ini kami analisis dari berbagai literature yaitu sosiologi hukum dan antropologi serta atura-aturan dan literature lainya yang berkorelasi dengan judul penulisan penelitian ini, secara umum dapat kami simpulakan faktor-faktor tersebut terdiri dari faktor internal dan faktor eksternal.

\section{Faktor Internal}

Faktor internal penyebab perilaku tindakan brutal dan kriminal geng motor, yaitu :

1. Sikap Mental yang Tidak Sehat dari anggota geng motor yaitu perilaku menyimpang tindakan brutal geng motor dapat pula disebabkan karena sikap mental yang tidak sehat. Sikap itu ditunjukan dengan tidak merasa bersalah atau menyesal atas perbuatannya, bahkan merasa senang. Contohnya : tindakan kriminal geng motor yang melakukan penganiyayaan terhadap seseorang di jalanan

2. Ketidakharmonisan Dalam Keluarga yaitu tidak adanya keharmonisan dalam keluarga anggota geng dapat menjadi penyebab terjadinya perilaku menyimpang yang terjadi akibat kesibukan orang tua sehingga meluoakan pehatian terhadap anak-anaknya khususnya terkait dimana anak itu bergaul dan dengan siapa . Contohnya : geng motor yang menggunakan obat-obatan terlarang dan minumminuman keras beralkohol karena faktor broken home.

3. Pelampiasan Rasa Kecewa yaitu seseorang atau anggota geng yang mengalami kekecewaan apabila tidak dapat mengalihkannya ke hal yang positif, maka ia akan berusaha mencari pelarian untuk memuaskan rasa kecewanya hal ini terkait dengan perasaan psikologi anak geng motor tersebut dalam melakukan 
manajemen emosinya, ini terjadi bisa karena kecewa dengan berbagai hal, teman, keluarga dll. Contohnya : bunuh diri.

4. Dorongan Kebutuhan Ekonomi yaitu perilaku menyimpang geng motor juga terjadi karena dorongan kebutuan ekonomi, hal ini maksudnya adalah kondisi ekonomi keluarga yang kurang sehingga muncul kesempatan untuk melakukan tindakan brutal dan kriminal yang justru dapat meresahkan masyarakat disekitarnya kemudian faktor ini juga bisa menjadi pemicu dalam melakukan tindakan asusila dan melanggar norma hidup masyarakat Contohnya : anggota geng yang melakukan perbuatan mencuri atau merampok.

5. Proses Belajar yang Menyimpang yaitu hal ini terjadi melalui interaksi sosial dengan orang-orang yang berprilaku menyimpang, terjdi akibat pergaulan yang salah dalam memilih dan memilah teman bermain sehingga akhirnya mereka masuk dalam geng motor tentunya anak tersebut harus mengikuti system dalam pergaulan geng motor tersebut. Contohnya: seorang anak remaja atau anak geng motor yang sering bergaul dengan kelompok remaja pengguna obat-obatan terlarang atau terlibat perkelahian lama-lama akan terpengaruh.

Dari uraian diatas jelas bahwa faktor internal sangat mempengaruhi terhadap adanya tindakan pelanggaran hukum yang dilakukan oleh geng motor dikota cirebon, oleh karena itu penting bagi semua elemen masyarakat untuk senantiasa melakukan tindakan prepentif agar mampu mengurangi faktor internal diatas supaya terjadi akselerasi dalam rangka mengurangi dan bahkan untuk mencegah tindakan brutal dan melanggar hukum anggota geng motor supaya ketentraman dan keamanan hidup dimasyarakat terjaga secara baik.

\section{Faktor ekternal}

Adapun faktor internal yang menjadi latar belakang tindakan brutal geng motor adalah sebagai berikut :

1. Materi peraturan hukum yaitu materi peraturan hukum maksudnya adalah pointpoint atau hal hal yang ada dalam peraturan hukum terkait peraturan terhadap anak masih banyak yang harus diperbaiki, bagaimana pun kedepan regulasi 
tentang pidana anak tidak harus mendapatkan hukuman dipenjara karena secara psikologi itu akan mengganggu perkembangan anak yang terkena hukuman pidana akibat tindakannya sebagai anggota geng motor yang melakukan pelanggaran hukum, selain itu perlu adanya evaluasi dan koreksi yang komperhensip terhadap materi-materi peraturan hukum terkait anak khususnya undang-undang perlindungan anak yaitu terhadap anggota geng motor yang notabenya masih anak-anak kemudian melakukan pelanggaran hukum apakah tepat hanya menitikberatkan kesalahan pada sianak tersebut, tanpa menganalisa tentang faktor dan sebab musabab mereka melakukan hal demikian. Berkaca dari hal diatas maka peraturan hukum terkait masalah dalam judul diatas juga menjadi point sebagai faktor eksternal terkait alasan mengapa tindakan brutal dan melanggar yang dilakuakan oleh geng motor marak terjadi, bisa juga kedepan dibuat regulasi oleh pemerintah daerah kota cirebon untuk mengatasi tindakan geng motor tersebut tentunya dengan melibatkan semua komponen masyarakat agar tercipta regulasi yang benar-benar memilki aspek sosiologis dan bertujuan untuk menentramkan masyarakat.

2. Aparat penegak hukum yaitu Aparat penegak hukum dalam hal ini pihak kepolisian, kejaksaan dan pengadilan sesuai dengan undang-undang memilki tanggung jawab besar terhadap pencegahan dan penanganan tindakan brutal geng motor, dari tiga aparat hukum mungkin pihak kepolisisan memilki peran strategis hal ini karena sesuai dengan fungsinya aparat kepolisian yaitu fungsi pencegahan dan fungsi penindakan. Fungsi pencegahan dilakukan sebelum terjadinya tindakan brutal geng motor hal ini bisa dilakuakan dengan melakukan pendataan terhadap anggota geng motor yang ada dikota cirebon kemudian melakukan pembinaan terkait materi-materi hukum khususnya terkait tindakan tindakan pelanggaran hukum pidana yang berakibat fatal bagi masa depannya, selain itu fungsi penindakan dilakukan terhadap anggota geng yang melakukan tindakan brutal sebisa mungkin melakukan tindakan dengan bahasa-bahasa anak-anak tidak dengan cara-cara yang menakutkan apalagi dengan kekerasan dalam melakukan 
penyidikannya, hal ini untuk mengantisifasi dampak buruk terhadap psikologi anak tersebut.

Dari fungsi diatas yang lebih menonjol sebenarnya adalah fungsi pencegahan, karena fungsi tersebut merupakan bagian yang bisa menurunkan tingkat brutalitas dari geng motor itu sendiri, dalam alam reformasi polri saat ini yang memilki jargon lebih dekat dengan masyarakat untuk itu peran melayani dan melindungi harus benar terjalankan khususnya terhadap problem hukum tindakan brutal geng motor yang ada dikota cirebon. Secara garis besar dari faktor eksternal adalah perlu adanya evaluasi terhadap peraturan dan kinerja aparat penegak hukum dalam melakukan penanganan terhadap tindakan brutal dan kadang-sampai menghabisi nyawa seseorang hal tersebut penting dalam rangka mengurangi tingkat brutalitas dan korban akibat tindakan asusila tersebut

\section{Penutup}

\section{Kesimpulan}

Dari urian masing-masing bab terkait judul penelitian yang penulis buat dapat disimpulkan hal hal sebagai berikut:

1. Bahwa tindakan geng brutal geng motor merupakan fenomena sosial akibat metamorfosa perkembangan tekhnologi dan informasi yang kemudian tidak terfilter dan tidak terakomodasi secara komferhensip tentang bagaimana tindakan pencegahanya, hal ini dengan analisa bahwa mayoritas dari anggota geng adalah anak yang memilki motor dan kerap melakukan tindakan kriminal dan melanggar norma norma sosial yang ada.

2. Bahwa akibat tindakan brutal dan melanggar hukum tersebut akhirnya masa depan dari anggota geng motor yang cenderung secara usia menurut undangundang perlindungan anak mereka masih dinamakan anak maka masa depan mereka suram karena harus menghadapi hidup di jeruji besi dan kebebasan mereka untuk berekspresi terampas, hal ini berbeda dengan anak anak diluar jeruji besi tahanan yang memiliki kebebasan untuk berekspresi dan menjalankan pendidikan sebagaimana layaknya anak normal seusianya. 
3. Tindakan brutal geng motor dari hasil wawancara dengan mereka dapat disimpulkan bahwa faktor-faktor yang melatarbelakangi mereka terdiri dari faktor internal dan faktor eksternal, adapun beberapa faktor internal diantaranya adalah sikap mental yang tidak Sehat dari anggota geng motor, ketidakharmonisan dalam keluarga, pelampiasan rasa kecewa, dorongan kebutuhan ekonomi, proses belajar yang menyimpang, kurangnya perhatian dan kasih sayang serta rendahnya tingkat pendidikan diantara mereka sedangkan faktor eksternal yaitu perlunya aparat penegak hukum untuk senantiasa melakukan tindakan prefentif dalam menangani perkara geng motor dan partisifasi masarakat dilingkunganya agar sigap melakukan tindakan prefentif juga.

\section{Saran}

1. Harus dibangunnya kesadaran dari steak holder bersama-sama dengan lembagalembaga yang konsern terhadap perlindungan anak dan para pihak terkait, seperti institusi pendidikan, kepolisian dan LSM untuk menciptakan kondisi daerah yang aman, tentram dan nyaman dari keberutal geng motor, yang mana geng motor ini terdiri dari kelompok usia anak-anak.

2. Harus ada penguatan kembali atau bahkan perumusan aturan yang dibangun oleh institusi pemerintah, semisal KPA (Komisi Perlindungan Anak) sebagai kepanjangan tangan pemerintah yang sudah jelas harus bertanggung jawab atas segala persoalan anak-anak yang terjadi. Hal ini dalam rangka melakukan perlindungan anak dari aktivitas yang merugikan 'bergabung dalam geng motor' yang identik dengan prilaku-prilaku berutal atau menyimpang.

3. Melihat fenomena diatas sudah saatnya pemerintah kota Cirebon membuat ketegasan aturan untuk menindak anak-anak yang tergabung dalam geng motor, hal ini tidak dapat ditolelir keberadaanya, karena geng motor memang suatu wadah yang illegal dan selalu membuat kondisi masyarakat luas tidak nyaman. Adapun untuk mengcounter hak masyarakat (red-anak), pihak kepolisian dalam hal ini yang memiliki wewenang untuk mengatur keamanan masyarakat dari aktivitas geng motor, telah memberikan wadah yang kemudian dapat dipantau atau dikontrol dan mungkin dapat melakukan kerjasama yang menguntungkan 
yaitu yang kita kenal dengan sebutan Club Motor. Club motor adalah sebuah organisasi legal yang tentunya terdiri dari kumpulan orang-orang yang suka melakukan aktivitas yang berhubungan dengan motor. Club motor ini adalah salah satu wadah pemberdayaan yang polisi lakukan hasil kerjasamanya dengan para pencinta motor yang tergabung dalam sebuah wadah atau club, sehingga tidak ada celah yang dapat club motor ini lakukan untuk berbuat berutal atau anarkis, karena aktivitas mereka selalu terkontrol oleh "kepolisian dalam hal ini bagian satlantas", dan mereka selalu mendapat binaan setiap satu bulan sekali dalam rangka membangun pemahaman dan mentransformsi informasi-informasi terkiat aktivitas club motor dan aturan-aturan yang harus dilaksanakan.

\section{Daftar Pustaka}

Kusumah, Mulyana W.1988, Kejahatan dan Penyimpangan : Suatu perspektif kriminologi, Jakarta, YLBHI, 1988

Rianto Adi : Diktat Sosiologi Hukum, Program Megister Hukum, Untag, Jakarta, 2009.

Romli Atmasasmita, Teori dan Kapita Selekta Kriminologi,penerbit Refika Aditama, Bandung, 2007

Soekanto, Soerjono, Pengantar Penelitian Hukum, Jakarta: UI Press, 1996

Kitab Undang-undang Hukum Pidana

UU No. 11 Tahun 2012 tentang Sistem Peradilan Anak. 